\title{
망막분지정맥폐쇄에 동반된 황반부종에서 베바시주맙치료 결과 Treatment Results of Bevacizumab for Macular Edema Secondary to Branch Retinal Vein Occlusion
}

\author{
최유진 ${ }^{1} \cdot$ 최영제 ${ }^{1} \cdot$ 조용운 ${ }^{1,2} \cdot$ 유웅선 ${ }^{1,2} \cdot$ 정인영 $^{1,2}$ \\ Yu-Jin Choi, MD ${ }^{1}$, Young Je Choi, $\mathrm{MD}^{1}$, Yong Wun Cho, MD, $\mathrm{PhD}^{1,2}$, Woong-Sun Yoo, MD, $\mathrm{PhD}^{1,2}$, \\ In Young Chung, $\mathrm{MD}, \mathrm{PhD}^{1,2}$ \\ 경상국립대학교 의과대학 안과학교실 ${ }^{1}$, 경상국립대학교 건강과학연구원 ${ }^{2}$ \\ Department of Ophthalmology, Gyeongsang National University School of Medicine ${ }^{l}$, Jinju, Korea \\ Gyeongsang Institute of Health Science, Gyeongsang National University', Jinju, Korea
}

\begin{abstract}
Purpose: To evaluate the results of treatment according to the method of intravitreal injection of bevacizumab for macular edema due to branch retinal vein occlusion (BRVO).

Methods: The clinical records of macular edema patients were analyzed retrospectively for a total of 62 eyes of 62 patients who were injected with bevacizumab into the vitreous as the first treatment for BRVO. Best-corrected visual acuity (BCVA), the findings of spectral-domain optical coherence tomography before and after injection, and prognosis-related factors were evaluated for 21 eyes that received the initial three monthly loading treatments and the 41 eyes that did not.

Results: Significant improvement in BCVA was observed in the group having received the initial three injections compared with the group who did not receive the injections at 3,6 , and 12 months $(p=0.025, p=0.019$, and $p=0.008$, respectively). The central macular thickness (CMT) showed greater improvement in the initial three injections group than the group without at 6 months $(p=0.034)$. Multivariate regression showed that the duration from the onset, the three loadings, BCVA, disorganization of the retinal inner layer (DRIL), and choroidal thickness were predictors related to visual gain $(p=0.044, p=0.047, p=0.004, p=0.045$, and $p=0.034$, respectively). Age, three loadings, BCVA, and DRIL were predictors related to final visual acuity $(p=0.045$, $p=0.046, p=0.002$, and $p=0.034$, respectively). Duration from the onset, CMT, and choroidal thickness were predictors related to CMT improvement ( $p=0.042, p=0.009$, and $p=0.015$, respectively).

Conclusions: In macular edema of BRVO, the initial three monthly intravitreal injections of bevacizumab provided superior treatment outcomes regarding short-term functional and anatomical improvements and long-term functional improvement, compared with methods that did not treat with the initial three monthly injections.
\end{abstract}

J Korean Ophthalmol Soc 2021;62(9):1207-1217

Keywords: Bevacizumab, Branch retinal vein occlusion, Macular edema, Three-monthly regimen

- Received: 2021. 5.3.

- Accepted: 2021. 8. 24.

- Address reprint requests to In Young Chung, MD, PhD Department of Ophthalmology, Gyeongsang National University Hospital, \#79 Gangnam-ro, Jinju 52727, Korea Tel: 82-55-750-8171, Fax: 82-55-758-4158

E-mail: inyoung@gnu.ac.kr

* This study will be announced by oral presentation at the 126th Annual Meeting of the Korean Opthalmological Society 2021.

* Conflicts of Interest: The authors have no conflicts to disclose.
망막정맥폐쇄는 당뇨망막병증 다음으로 두 번째로 흔한 망막혈관질환이다. ${ }^{1}$ 망막정맥폐쇄는 폐쇄 부위에 따라 망 막분지정맥폐쇄, 망막중심정맥폐쇄, 절반망막중심정맥폐쇄 로 분류되며 망막분지정맥폐쇄는 망막중심정맥폐쇄에 비 해 4 배 발생 빈도가 높은 것으로 알려져 있다. ${ }^{2}$ 황반부종은 망막분지정맥폐쇄에서 시력감소를 일으키는 가장 중요한 원인으로, 혈관폐쇄의 결과로 발생한 허혈은 혈액망막장벽 
의 파괴 및 혈관내피성장인자, interleukin (IL)-6, IL-8, IL-12, IL-13 등의 염증인자를 유발하여 혈관 투과성을 증가시켜 손상된 모세혈관 내피세포 틈으로 체액과 혈장 성분이 축 적되어 이차적으로 황반부종이 발생하게 된다. ${ }^{3-5}$

시력감소를 보이는 황반부종에 대한 치료 방법으로 초기 에는 Branch Vein Occlusion Study ${ }^{6}$ 와 Standard Care vs. Corticosteroid for Retinal Vein Occlusion Study ${ }^{7}$ 의 발표 이 후 격자레이저광응고술이 황반부종의 주된 치료였다. 또한 유리체내 스테로이드주입술을 시행해 볼 수 있으나 백내장, 안압상승과 같은 합병증이 발생할 수 있어 사용하는 데 제 약이 있었다. ${ }^{8-10}$ 하지만 유리체내 항혈관내피성장인자 주사 치료 도입 후 여러 연구들에서 중심망막두께 감소와 시력 호전을 보고하였고 Ranibizumab for Branch Retinal Vein Occlusion Study ${ }^{11}$ 와 VIBRANT study ${ }^{12}$ 에서 격자레이저광 응고술보다 더 좋은 시력호전을 보여주고 있으며 현재 최
근에는 유리체내 항혈관내피성장인자 주입술이 망막분지 정맥폐쇄의 황반부종에 대한 일차치료로 많이 시행되고 있 다. ${ }^{13-15}$

유리체내 항혈관내피성장인자 주입술은 주사 후 대부분 호전 상태를 유지하기 위해 재주사치료를 필요로 하고, 베 바시주맙(Avastin ${ }^{\circledR}$, Genentech Inc., Oceanside, CA, USA; The Roche Group, Basel, Switzerland)은 비용적 측면을 고 려할 때 상대적으로 저렴하여 망막정맥폐쇄에 동반되는 황 반부종에 널리 사용되는 약제이다. ${ }^{16}$ 하지만 아직까지 유리 체내 베바시주맙주입술 최적의 스케줄 방법에 대하여 결정 된 바는 없다. 이에 본 연구에서는 망막분지정맥폐쇄로 인 한 황반부종에 대한 치료로서 유리체내 베바시주맙주입술 을 초기 한 달 간격으로 3 회 시행 이후 부종 재발 시 추가 적으로 주사를 시행한 군과 초기 3회 로딩 치료를 하지 않 은 군을 비교하여 시력 및 중심황반두께를 분석하였고, 기
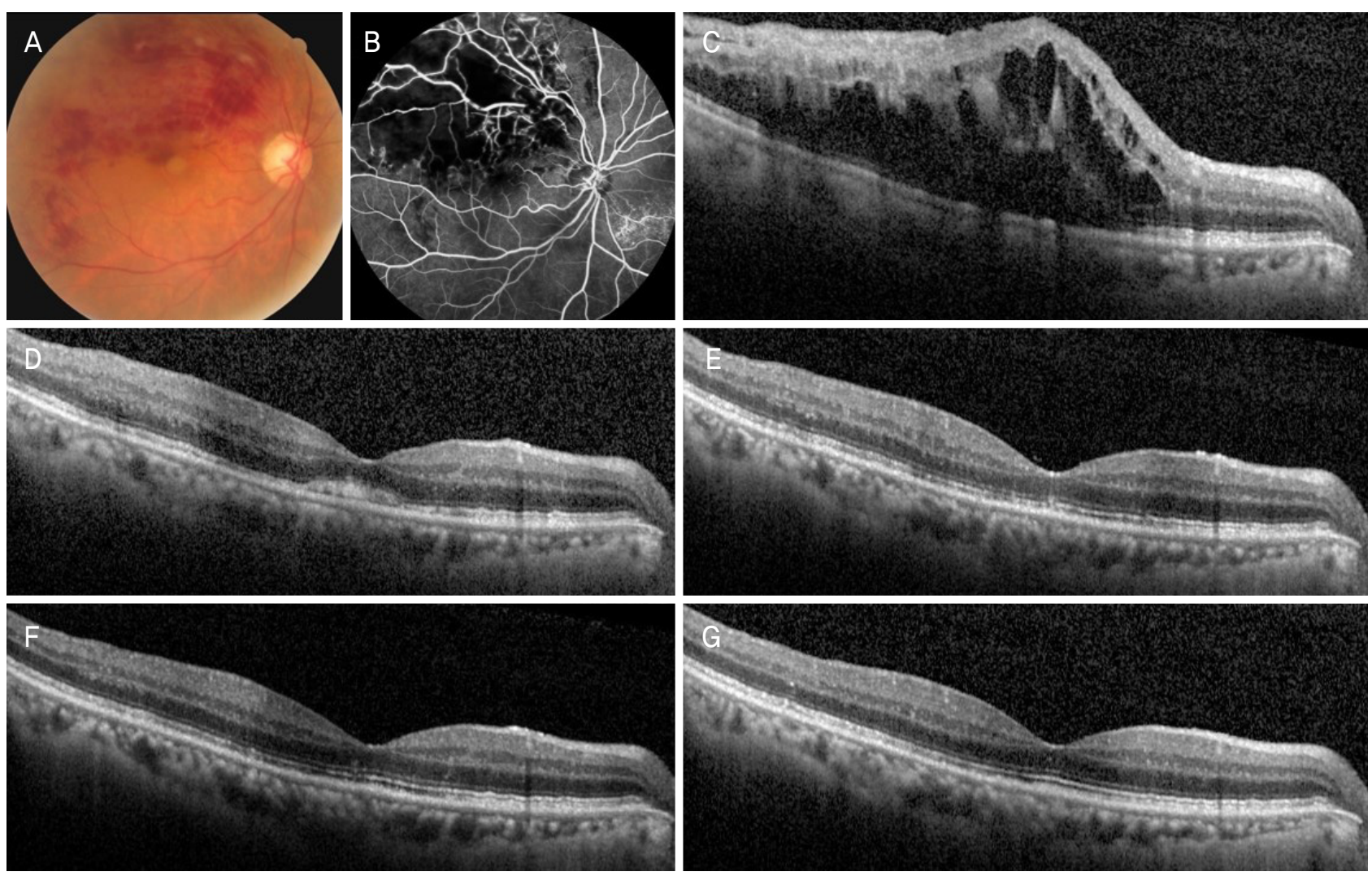

Figure 1. Fundus photography and fluorescein angiography (FAG) and optical coherence tomography (OCT) images of case of macular edema secondary to branch retinal vein occlusion treated with three initial monthly intravitreal bevacizumab injections regimen. (A, B) At initial visit, intraretinal hemorrhages and cotton-wool spots was seen in fundus photograph. At baseline, retinal nonperfusion, capillary telangiectasia, microaneurysms were seen in FAG. (C) At initial visit, OCT shows severe macular edema. (D) Macular edema was decreased after 1 st bevacizumab injection, but remaining subretinal fluid was seen. (E) Subretinal fluid was absorbed completely after 2nd bevacizumab injection. (F) Macular edema sustained resolution, after 3rd bevacizumab injection. (G) At 12 months, the patient remains stable without recurrence. The patient did not receive any additional injections after three injections. 
능적 호전과 해부학적 호전에 영향을 미치는 예측 인자에 대하여 알아보고자 하였다.

\section{대상과 방법}

본 연구는 2016년 11월부터 2019년 10월까지 망막분지 정맥폐쇄에 동반된 황반부종으로 진단받고 유리체내 베바 시주맙주입술을 시행받은 환자에서 연구 기준에 적합한 62 명 62 안을 대상으로 의무기록을 후향적으로 분석하였으 며 헬싱키선언에 입각한 생명의학연구윤리 심사위원회의 승인하에 진행되었다(승인 번호: 2021-03-016). 환자들은 유리체내 베바시주맙주입술 스케줄 방법에 따라 두 군으로 분류되었다. 황반부종에 대하여 초기 한 달 간격으로 3 회 로딩 치료에 성공한 21 안과 그렇지 않은 그룹 41 안의 두 군으로 분류하였다. 초기 한 달 간격으로 3 회 주입 이후 필 요 시에 추가적으로 주입한 군은 3 monthly군으로 정의하 였고, 3 회 로딩으로 치료하지 않은 군은 non-3 monthly군으 로 정의하였다(Fig. 1). 연구에 포함된 환자는 망막분지정맥 폐쇄로 진단되고 진단 당시 최대교정시력 20/40-20/320, 빛 간섭단층촬영에서 중심황반두께가 $300 \mu \mathrm{m}$ 이상인 경우, 최 초 치료로 유리체내 베바시주맙주입술을 시행받고 12개월 이상 경과 관찰한 환자를 대상으로 하였다. 다음의 경우는 연구 대상에서 제외하였다: 1) 이전에 망막분지정맥폐쇄로 유리체내 트리암시놀론 혹은 항혈관내피성장인자 주입술 을 받은 경우, 2) 시력에 유의한 영향을 줄 수 있는 각막혼 탁, 시축을 침범하는 백내장, 유리체혼탁, 유리체출혈 같은 매체 혼탁이 있는 경우, 3) 안구내 염증이 있었던 경우, 4) 유 리체절제술 과거력이 있는 경우, 5) 연령관련황반변성, 당 뇨황반부종, 황반원공 등과 같이 황반부 기능에 영향을 미 칠 수 있는 다른 질환을 보이는 경우, 5) 최근 6개월 이내 뇌혈관 및 심혈관 질환이 있었던 경우.

대상 환자들은 최대교정시력, 안압, 세극등현미경검사, 안저검사, 빛간섭단층촬영(HRA Spectralis+OCT, Heidelberg Engineering, Heidelberg, Germany), 형광안저혈관조영(HRA2 FAG, Heidelberg engineering Gmbh, Heidelberg, Germany) 을 시행하였다. 형광안저혈관조영을 통해 망막의 허혈 정 도를 평가하였고 출혈이 많은 급성기를 고려하여 출혈 흡 수 경과에 따라 1-4개월 내에 시행되었다. 모세혈관 비관류 는 형광안저혈관조영에서 모세혈관계의 탈락이 발견되는 경계에서부터의 면적을 시신경유두 크기를 기준으로 범위 를 구분하였으며, 출혈에 의하여 형광안저혈관조영에서 차 단 현상으로 모세혈관계의 거짓 탈락이 관찰되는 경우 안 저사진과 비교하여 구별하였다. 비관류 범위가 시신경유두 의 5 배 이상의 크기인 경우 허혈성 망막분지정맥폐쇄 (ischemic branch retinal vein occlusion [ischemic BRVO]) 로 정의하였으며 시신경유두의 5 배보다 작은 경우 비허혈 성 망막분지정맥폐쇄(non-ischemic BRVO)로 정의하였다. ${ }^{17}$ 빛간섭단층촬영을 통해 중심황반두께(central macular thickness), 망막내층손상(disorganization of retinal inner layer), 장액망막박리(serous retinal detachment), 바깥경계막(external limiting membrane) 손상, 빛수용체타원체구역(elipsoid zone) 손상, 맥락막두께를 평가하였다. 중심황반두께는 빛간섭단 층촬영 사진을 이용하여 내경계막으로부터 브루크막까지 의 거리를 수직으로 측정하였다. 망막내층손상의 정의는 망막중심오목을 중심으로 $2,000 \mu \mathrm{m}$ 범위 내의 신경절세포 층, 내망상층복합체, 내핵층과 외망상층 간의 경계가 불명 확한 것으로 정의하였다. ${ }^{18}$ 맥락막두께는 망막색소상피의 후면부터 맥락막공막 경계부까지의 거리를 망막중심오목 및 망막중심오목으로부터 비측과 이측으로 $500 \mu \mathrm{m}$ 간격으 로 총 7군데에서 수직으로 측정한 평균값을 사용하였다. ${ }^{19}$

모든 환자들은 $0.5 \%$ proparacaine hydrochloride (Alcaine ${ }^{\circledR}$, Alcon, Fort Worth, TX, USA)으로 시술 전 점안마취한 뒤 povidone iodine으로 속눈썹과 눈주위를 소독하고, 개검기 를 끼우고 $1.25 \%$ povidone iodine으로 세척한 뒤 각막윤부 에서 하외측 $3.0 \mathrm{~mm}$ 혹은 $3.5 \mathrm{~mm}$ 부위의 섬모체 평면부를 통해 30게이지 일회용 바늘을 이용하여 유리체내 베바시주 맙 $(1.25 \mathrm{mg} / 0.05 \mathrm{~mL})$ 을 주입하였다. 시술 후 감염 예방을 위하여 $0.5 \%$ moxifloxacin hydrochloride (Moroxacin ${ }^{\circledR}$, Hanmi Pharm., Seoul, Korea)를 1주일간 하루 4회 사용하였다. 재 치료는 1) 중심황반두께가 $300 \mu \mathrm{m}$ 이상인 경우, 2) 망막하 액이나 망막내액이 새롭게 발병하는 경우에 유리체내 베바 시주맙재주입술을 시행하였다.

유리체내 베바시주맙주입술 시행 전과 시술 3 개월, 6 개월, 9 개월, 12 개월의 최대교정시력과 빛간섭단층촬영을 이용한 중심황반두께를 측정하여 두 군에서 시술 후의 효과를 비교 분석하였다. 최대교정시력은 통계학적 분석을 위해 분석 전 logarithm of the minimum angle of resolution (logMAR) 값으로 환산하여 분석하였다. 통계 분석에는 SPSS 프로그 램(SPSS version 21.0, software for windows; IBM Corp., Armonk, NY, USA)을 이용하였다. Kolmogorov-Smirnov test와 Shapiro-Wilk test을 통하여 정규성 검정을 하고 관찰 각 시점에서 두 군 간의 비교는 student's $t$-test를 사용하였 으며 수술 전후의 비교는 paired $t$-test로 분석하였다. 해부 학적 호전과 기능적 호전과 관련된 예측인자를 알아보기 위해 단변량 회귀분석과 다변량 회귀분석을 시행하였다. $p$ 값이 0.05 미만인 경우에 통계적으로 유의한 것으로 정의 하였다. 


\section{결 과}

전체 62 명 62 안의 환자군 중, non-3 monthly군은 41 명 41안으로 평균 나이는 $63.18 \pm 14.72$ 세였으며, 3 monthly군 은 21명 21안으로 평균 나이는 $60.25 \pm 11.69$ 세였다. 나이, 성별 비율, 당뇨, 고혈압 기저질환, 위수정체안, 허혈성 망 막분지정맥폐쇄의 비율에 대하여 두 군 간의 차이는 없었 다. 증상 발현부터 치료까지의 기간은 non-3 monthly군에 서 $25.6 \pm 9.25$ 일, 3 monthly군에서 $31.58 \pm 10.15$ 일로 통계 적으로 두 군 간의 유의한 차이는 없었다. 환자들의 치료 전 각 특성들에 대하여 Table 1에 나타내었다. Non-3 monthly 군에서 유리체내 베바시주맙주입술 치료에 반응하지 않은 증례는 베바시주맙과 트리암시놀론 혼합제제로 약제를 전 환한 환자가 3 안, 라니비주맙으로 약제를 전환한 환자가 4 안, 덱사메타손 삽입물로 약제를 전환한 환자가 2 안이었 고, 3 monthly군에서 유리체내 베바시주맙주입술 치료에 반응하지 않은 증례는 베바시주맙과 트리암시놀론 혼합제 제로 약제를 전환한 환자가 2안, 라니비주맙으로 약제를 전 환한 환자가 2 안이었다.

유리체내 주사 치료 전 최대교정시력은 non-3 monthly군

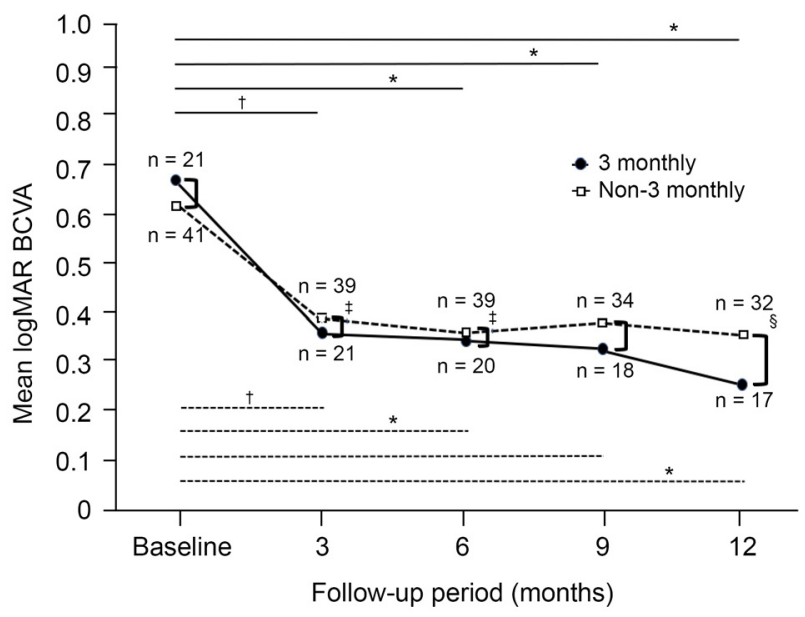

Figure 2. Mean logarithm of the minimal angle of resolution ( $\log$ MAR) best-corrected visual acuity (BCVA) from baseline to 12 months. Mean BCVA was improved 3, 6, 9, 12 months in 3 monthly group, and at 3, 6, 12 months in non-3 monthly group compared with baseline values $\left({ }^{*} p<0.05,{ }^{\dagger} p<0.01\right.$, paired $t$-test). Mean BCVA was worse in non-3 monthly group than in 3 monthly group at $3,6,12$ months $\left({ }^{\ddagger} p<0.05,{ }^{\S} p<0.01\right.$, student's $t$-test).

Table 1. Baseline charcteristics of patients

\begin{tabular}{lccc}
\hline Characteristic & Non-3 monthly group $(\mathrm{n}=41)$ & 3 Monthly group $(\mathrm{n}=21)$ & $p$-value \\
\hline Age (years) & $63.18 \pm 14.72$ & $60.25 \pm 11.69$ & 0.315 \\
Sex & & & 0.732 \\
Male & $18(43.9)$ & $8(38.1)$ & \\
Female & $23(56.1)$ & $5(23.8)$ & 0.334 \\
DM & $7(17.1)$ & $9(42.9)$ & 0.812 \\
HTN & $18(43.9)$ & $31.58 \pm 10.15$ & 0.534 \\
Duration from onset (days) & $25.65 \pm 9.25$ & $3.9 \pm 1.0$ & 0.097 \\
Number of injections & $3.6 \pm 1.7$ & & 0.396 \\
Lens status & & $5(23.8)$ & \\
Pseudophakic & $11(26.8)$ & $16(76.2)$ & $0.69 \pm 0.30$ \\
Phakic & $30(73.2)$ & & \\
BCVA (logMAR) & $0.61 \pm 0.29$ & $14(66.7)$ & 0.541 \\
Nonperfusion status & & $7(33.3)$ & \\
Ischemic BRVO & $25(60.9)$ & $318.33 \pm 156.24$ & \\
Non-ischemic BRVO & $16(39.1)$ & $3(14.3)$ & 0.635 \\
Central macular thickness $(\mu \mathrm{m})$ & $507.15 \pm 145.21$ & $14(66.7)$ & 0.258 \\
Foveal ERM & $4(9.8)$ & $13(61.9)$ & 0.518 \\
DRIL & $28(68.3)$ & $12(57.1)$ & 0.785 \\
Disrupted ELM & $23(56.1)$ & $14(66.7)$ & 0.723 \\
SRD & $21(51.2)$ & $261.83 \pm 29.28$ & 0.642 \\
Disrupted EZ & $26(63.4)$ & 0.801 \\
Choroidal thickness $(\mu \mathrm{m})$ & $257.42 \pm 20.35$ & \\
\hline
\end{tabular}

Student's $t$-test for continuous variables and chi-square or Fisher's exact test for dichotomous variables were used to compare the parameters between the groups. Values are presented as mean \pm standard deviation or number $(\%)$.

$\mathrm{DM}=$ diabetes mellitus; HTN = hypertension; BCVA = best-corrected visual acuity; logMAR = logarithm of the minimal angle of resolution; BRVO = branch retinal vein occlusion; ERM = epiretinal membrane; DRIL = disorganization of retinal inner layers; SRD = serous retinal detachment; ELM = external limiting membrane; EZ = ellipsoid zone. 
에서 $0.61 \pm 0.29 \log \mathrm{MAR}, 3$ monthly군에서 $0.69 \pm 0.30$ $\operatorname{logMAR}$ 로 두 군 간의 차이는 없었다. 유리체내 주사 후 최 대교정시력이 non-3 monthly군은 시술 3 개월, 6 개월, 9개 월, 12 개월에 각각 $0.39 \pm 0.31,0.36 \pm 0.29, \pm 0.38 \pm 0.25$, $0.36 \pm 0.27 \operatorname{logMAR}$ 이었으며 $(p=0.003, p=0.018, p=0.249$, $p=0.045$ ), 3 monthly군은 시술 3 개월, 6 개월, 9개월, 12 개월

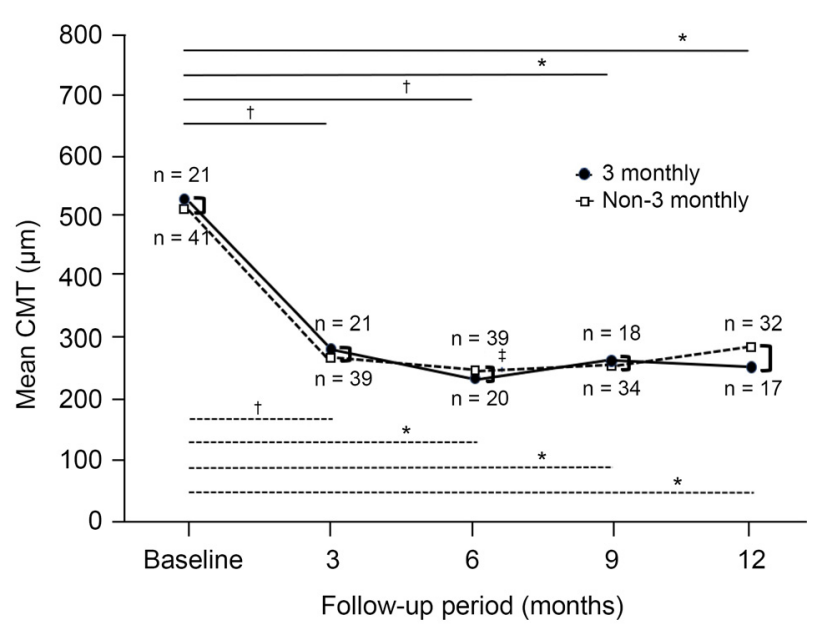

Figure 3. Mean central macular thickness (CMT) from baseline to 12 months. Mean CMT was decreased at 3, 6, 9, 12 months in 2 groups with baseline values $\left({ }^{*} p<0.05,{ }^{\dagger} p<0.01\right.$, paired $t$-test). Mean CMT was greater in non-3 monthly group than in 3 monthly group at 6 months $\left({ }^{\ddagger} p<0.05\right.$, student's $t$-test).
에 각각 $0.36 \pm 0.26,0.34 \pm 0.28,0.32 \pm 0.31,0.25 \pm 0.22$

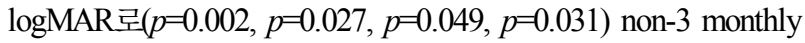
군과 3 monthly군 두 군 모두 치료 전과 비교하여 12 개월 째 유의한 시력개선을 보였다. 두 군을 비교하였을 때 최대 교정시력은 3 개월, 6 개월, 12 개월째 3 monthy군에서 non-3 monthly군보다 더 큰 유의한 시력호전이 있었다 $(p=0.025$, $p=0.019, p=0.008$ ) (Fig. 2).

유리체내 주사치료 전 중심황반두께는 non-3 monthly군 에서 $507.15 \pm 145.21 \mu \mathrm{m}, 3$ monthly군에서 $518.33 \pm$ $156.24 \mu \mathrm{m}$ 로 두 군 간의 차이는 없었다. 유리체내 주사 후 중심황반두께가 non-3 monthly군은 시술 3개월, 6개월, 9개월, 12 개월에 각각 $268.72 \pm 87.41,248.13 \pm 68.22,261.84 \pm$ $70.42,281.31 \pm 75.23 \mu \mathrm{m}$ 였으며 $(p=0.007, p=0.013, p=0.028$, $p=0.034$ ), 3 monthly군은 시술 3 개월, 6 개월, 9 개월, 12 개월 에 각각 $276.31 \pm 95.75,237.35 \pm 65.91,263.43 \pm 83.72$, $257.14 \pm 89.51 \mu \mathrm{m}$ 로 $(p=0.003, p=0.009, p=0.041, p=0.018)$ non-3 monthly군과 3 monthly군 두 군 모두에서 치료 전과 비교하여 12 개월째 유의한 중심황반두께의 감소를 보였다. 두 군을 비교하였을 때 중심황반두께는 6 개월째 3 monthy 군에서 non-3 monthly군보다 더 큰 유의한 중심황반두께 호전을 보였다 $(p=0.034)$ (Fig. 3).

기능적 호전과 해부학적 호전에 영향을 미치는 예측인자 에 관하여 알아보기 위해 단변량 회귀분석과 다변량 회귀 분석을 시행하였다. 기능적 호전에 대하여 시력개선 정도

Table 2. Univariate and multivariate regression analysis for baseline predictive factors associated with visual gain

\begin{tabular}{|c|c|c|c|c|}
\hline \multirow{2}{*}{ Factor } & \multicolumn{2}{|c|}{ Univariate analysis } & \multicolumn{2}{|c|}{ Multivariate analysis } \\
\hline & Beta coefficient & $p$-value & Beta coefficient & $p$-value \\
\hline Age & -0.025 & $0.009^{*}$ & -0.021 & 0.061 \\
\hline Sex & -0.013 & 0.815 & & \\
\hline $\mathrm{DM}$ & -0.231 & 0.359 & & \\
\hline HTN & 0.073 & 0.534 & & \\
\hline Duration from onset & -0.256 & $0.035^{\dagger}$ & -0.221 & $0.044^{\dagger}$ \\
\hline 3 Loading & 0.229 & $0.039^{\dagger}$ & 0.198 & $0.047^{\dagger}$ \\
\hline Lens status & 0.017 & 0.787 & & \\
\hline BCVA & -0.548 & $0.002^{*}$ & -0.418 & $0.004^{*}$ \\
\hline Nonperfusion status & -0.197 & 0.129 & & \\
\hline Central macular thickness & -0.004 & $0.021^{\dagger}$ & -0.002 & 0.159 \\
\hline Foveal ERM & 0.027 & 0.713 & & \\
\hline DRIL & -0.311 & $0.038^{\dagger}$ & -0.223 & $0.045^{\dagger}$ \\
\hline SRD & -0.131 & 0.358 & & \\
\hline Disrupted ELM & -0.009 & 0.815 & & \\
\hline Disrupted EZ & -0.284 & 0.431 & & \\
\hline Choroidal thickness & 0.218 & $0.027^{\dagger}$ & 0.207 & $0.034^{\dagger}$ \\
\hline
\end{tabular}

Visual gain was defined as BCVA (logMAR) at 12 months minus BCVA (logMAR) at baseline.

$\mathrm{DM}=$ diabetes mellitus; HTN = hypertension; BCVA = best-corrected visual acuity; ERM = epiretinal membrane; DRIL = disorganization of retinal inner layers; SRD = serous retinal detachment; ELM = external limiting membrane; EZ = ellipsoid zone; logMAR = logarithm of the minimal angle of resolution.

${ }^{*} p<0.01 ;{ }^{\dagger} p<0.05$. 
와 최종 시력 결과에 대하여 분석하였다. 시력개선 정도에 대하여 단변량 회귀분석 결과 연령, 증상 발현부터 치료까 지의 기간, 3회 로딩, 최대교정시력, 중심황반두께, 망막내 층손상, 맥락막두께가 시력호전과 관련된 예측인자로 $(p=0.009$, $p=0.035, p=0.039, p=0.002, p=0.021, p=0.038, p=0.027)$, 다
변량 회귀분석 결과 증상 발현부터 치료까지의 기간, 3회 로딩, 최대교정시력, 망막내층손상, 맥락막두께가 시력호전 과 관련된 예측인자로 나타났다 $(p=0.044, p=0.047, p=0.004$, $p=0.045, p=0.034$ ) (Table 2). 최종 시력에 대하여 단변량 회귀분석 결과 연령, 증상 발현부터 치료까지의 기간, 3 회

Table 3. Univariate and multivariate regression analysis for baseline predictive factors associated with visual acuity at 12 month

\begin{tabular}{lccc}
\hline \multirow{2}{*}{ Factor } & \multicolumn{2}{c}{ Univariate analysis } & \multicolumn{2}{c}{ Multivariate analysis } \\
\cline { 2 - 3 } \cline { 4 - 4 } Age & Beta coefficient & $p$-value & Beta coefficient \\
Sex & -0.298 & $0.039^{*}$ & -0.253 \\
DM & -0.026 & 0.784 & \\
HTN & -0.149 & 0.098 & \\
Duration from onset & 0.038 & 0.546 & -0.125 \\
3 Loading & -0.216 & $0.046^{*}$ & 0.214 \\
Lens status & 0.325 & $0.037^{*}$ & 0.093 \\
BCVA & 0.021 & 0.682 & $0.046^{*}$ \\
Nonperfusion status & 0.735 & $0.006^{\dagger}$ & -0.136 \\
Central macular thickness & -0.317 & $0.034^{*}$ & $0.002^{\dagger}$ \\
Foveal ERM & -0.201 & 0.063 & 0.087 \\
DRIL & -0.118 & 0.136 & -0.318 \\
SRD & -0.348 & $0.032^{*}$ & $0.034^{*}$ \\
Disrupted ELM & -0.127 & 0.149 & \\
Disrupted EZ & -0.002 & 0.813 & \\
Choroidal thickness & -0.207 & 0.061 & \\
\hline
\end{tabular}

$\mathrm{DM}=$ diabetes mellitus; HTN = hypertension; BCVA = best-corrected visual acuity; ERM = epiretinal membrane; DRIL = disorganization of retinal inner layers; SRD = serous retinal detachment; ELM = external limiting membrane; EZ = ellipsoid zone.

${ }^{*} p<0.05 ;{ }^{\dagger} p<0.01$.

Table 4. Univariate and multivariate regression analysis for baseline predictive factors associated with anatomical gain

\begin{tabular}{lccc}
\hline \multirow{2}{*}{ Factor } & \multicolumn{2}{c}{ Univariate analysis } & \multicolumn{2}{c}{ Multivariate analysis } \\
\cline { 2 - 3 } Age & Beta coefficient & $p$-value & Beta coefficient \\
Sex & -0.034 & 0.091 & \\
DM & 0.012 & 0.325 & \\
HTN & -0.207 & 0.391 & -0.271 \\
Duration from onset & 0.094 & 0.458 & \\
3 Loading & -0.312 & $0.023^{*}$ & $0.042^{*}$ \\
Lens status & 0.148 & 0.072 & \\
BCVA & 0.021 & 0.384 & 0.326 \\
Nonperfusion status & -0.432 & 0.254 & 0.756 \\
CMT & 0.492 & $0.028^{*}$ & 0.076 \\
Foveal ERM & 0.841 & $0.004^{\dagger}$ & $0.009^{\dagger}$ \\
DRIL & -0.121 & 0.315 & 0.253 \\
SRD & -0.354 & $0.015^{*}$ & 0.147 \\
Disrupted ELM & 0.293 & $0.031^{*}$ & 0.312 \\
Disrupted EZ & 0.032 & 0.614 & 0.295 \\
Choroidal thickness & 0.028 & 0.548 & $0.015^{*}$ \\
\hline
\end{tabular}

Anatomical gain was defined as CMT at 12 months minus CMT at baseline.

$\mathrm{DM}=$ diabetes mellitus; HTN = hypertension; BCVA = best-corrected visual acuity; CMT = central macular thickness; ERM = epiretinal membrane; DRIL = disorganization of retinal inner layers; $\mathrm{SRD}=$ serous retinal detachment; ELM $=$ external limiting membrane; EZ $=$ ellipsoid zone.

${ }^{*} p<0.05 ;{ }^{\dagger} p<0.01$. 
로딩, 최대교정시력, 망막비관류 정도, 망막내층손상이 최 종 시력과 관련된 예측인자로 $(p=0.039, p=0.046, p=0.037$, $p=0.006, p=0.034, p=0.032)$, 다변량 회귀분석 결과 연령, 3 회 로딩, 최대교정시력, 망막내층손상이 최종 시력과 관련된 예측인자로 나타났다 $(p=0.045, p=0.046, p=0.002, p=0.034)$ (Table 3). 해부학적 호전에 대하여 단변량 회귀분석 결과 증상 발현부터 치료까지의 기간, 망막비관류 정도, 중심황반 두께, 망막내층손상, 장액망막박리, 맥락막두께가 중심황반 두께 호전과 관련된 예측인자로 $(p=0.023, p=0.028, p=0.004$, $p=0.015, p=0.031, p=0.007)$, 다변량 회귀분석 결과 증상 발 현부터 치료까지의 기간, 중심황반두께, 맥락막두께가 중심 황반두께 호전과 관련된 예측인자로 나타났다 $(p=0.042$, $p=0.009, p=0.015$ ) (Table 4). 1년 시점에서 유리체내 베바 시주맙주입술 평균 주사 횟수는 non-3 monthly군에서 3.6 \pm 1.7 회, 3 monthly군에서 $3.9 \pm 1.0$ 회였다. 12 개월간 유리 체내 베바시주맙주입술 시행으로 안내염, 유리체출혈, 뇌경 색 및 심근경색의 혈전색전성 질환과 같은 심각한 합병증 은 나타나지 않았다.

\section{고 찰}

망막분지정맥폐쇄는 동정맥 교차 부위에 혈관이 막혀 망 막출혈이 나타나고 황반부종이나 허혈이 발생하여 시력장 애를 일으킨다. ${ }^{20}$ 허혈로 인한 신경조직 손상으로 세포 내 외의 고장성 환경이 형성되어 부종이 발생하고, 정맥의 혈 류가 차단되면서 혈관내 압력상승과 황반 미세혈관으로 가 는 혈류가 감소되어 혈액망막장벽의 파괴와 혈관투과성을 증가시켜 혈장성분이나 체액이 망막의 외망상층이나 내과 립층 등에 누출되어 황반부종이 발생한다. ${ }^{21,22}$ 황반부종이 동반된 안구의 방수에서 혈관내피성장인자, 태반성장인자, 혈소판유래성장인자, IL-6, IL-8 등의 염증인자와 같은 사 이토카인이 고농도로 축적되며 황반부종에 중요한 역할을 하는 것으로 알려져 있다. 23,24 이러한 황반부종의 기전에 따 라 유리체내 항혈관내피성장인자 주입술 혹은 유리체내 스 테로이드 주입술이 치료 방법으로 사용되면서 황반부종의 치료에 많은 발전이 이루어져 왔다. 그러나 스테로이드 주 사의 경우 안압상승, 백내장 발생, 안내염 등 합병증 발생 가능성으로 ${ }^{25}$ 사용 대상에 제약이 있고, 현재 항혈관내피성 장인자 주입술이 망막분지정맥폐쇄의 황반부종의 일차적 치료로 사용되고 있다. 망막분지정맥폐쇄성 황반부종에 대 한 급여가 허용된 라니비주맙, 애플리버셉트와 같은 약제 들의 현재 급여 적용 기준은 1) 반대편 눈이 실명(최대교정 시력 0.3 이하의 노동력 상실 실명)인 경우, 2) 반대편 눈의 최대교정시력이 0.4 이상인 경우는 발병 2-3개월이 경과하
여도 $300 \mu \mathrm{m}$ 이상의 황반부종이 지속되면서 최대교정시력 이 0.5 이하인 경우다. 또한 단안당 총 5 회 이내에서만 급 여가 적용될 수 있다. 이처럼 증상 발현 기간과 시력 기준 에 대한 엄격한 급여 조건의 기준이 있고, 횟수 제한이 있 어 유리한 가격 측면과 적극적인 조기치료를 위해 실제 임 상에서는 off label 약제인 베바시주맙을 많이 선택하기도 한다.

본 연구에서는 유리체내 베바시주맙을 초기 한 달 간격 으로 3 회 로딩 치료에 성공한 군과 그렇지 않은 군을 12 개 월간 관찰하였다. 그 결과 최대교정시력( $\log M A R)$ 은 non-3 monthly군보다 3 monthly군에서 3개월, 6 개월, 12 개월째 유의하게 더 큰 호전을 보였다. 하지만 중심황반두께는 3 monthly군에서 non-3 monthly군보다 6개월째 유의하게 더 큰 감소를 보였으나 다른 시점에서는 통계적으로 유의 하지 않았다. 본 연구에서는 3 monthly군이 non-3 monthly 군에 비하여 치료 결과에서 기능적 및 해부학적 우위를 보 였으나 이와 다르게 초기 3회 주입군과 초기 1회 주입군을 비교한 Miwa et $\mathrm{al}^{26}$ 과 Ito et $\mathrm{al}^{27}$ 연구에서는 최대교정시력 이 두 군 간의 차이가 없었고, 초기 3 회 주입군과 pro re nata (PRN) 주입군을 비교한 $\mathrm{Ahn} \mathrm{et} \mathrm{al}^{28}$ 연구에서도 최대 교정시력과 중심황반두께 변화에 대하여 두 군 간의 차이 를 보이지 않았다. 그러나 Miwa et $\mathrm{al}^{26}$ 의 연구에서 기저 최 대교정시력이 20/40 이하인 환자들과 20/40을 초과하는 환 자들로 나누어 분석한 결과, 초기 최대교정시력이 불량한 경우 12 개월의 관찰 기간 동안 초기 3 회 주입군에 비하여 초기 1 회 주입군의 시력과 중심황반두께가 더 나쁜 경향을 보인 반면, 초기 최대교정시력이 좋은 경우 12 개월의 관찰 기간 동안 초기 3 회 주입군과 초기 1 회 주입군의 시력과 중 심황반두께가 상대적으로 유사한 경향을 보임을 보고하였 다. Miwa et $\mathrm{al}^{26}$, Ito et $\mathrm{al}^{27}$ 와 $\mathrm{Ahn}$ et $\mathrm{al}^{28}$ 의 연구에서는 초 기 3회 주입군이 비교군에 비하여 주사 횟수가 많았으며, 본 연구에서는 통계적 의미를 보이지는 않았지만 주사 횟 수가 3 monthly군에서 non-3 monthly군에 비하여 조금 더 많았다. 하지만 본 연구는 후향적 연구로 1) 초기 3회 로딩 을 하려 하였으나 경과 관찰이 안 된 경우, 2) 환자의 의지 에 따라 의사의 지시를 따르지 않아 로딩을 하지 못한 경우 에 대하여 엄밀한 의미의 PRN군으로 보기는 어려워 non-3 monthly군으로 구분하여 정의하였고, 이를 참고하여 결과 를 해석해야 할 것으로 보인다. 또한 본 연구는 기존 연구 들과 비교하여 연구 대상 및 재주사 기준에서 차이점이 있 다. Ahn et $\mathrm{al}^{28}$ 의 연구에서는 황반부종이 동반된 망막분지 정맥폐쇄의 환자에서 최대교정시력이 20/30 이하인 환자들 을 연구 대상으로 하였으나 본 연구에서는 최대교정시력 20/40-20/320의 환자들을 연구 대상에 포함시켰고, Ito et 
$\mathrm{al}^{27}$ 의 연구와 비교해 볼 때 진단 시 평균 최대교정시력이 본 연구에서 더 낮은 것으로 볼 때 망막분지정맥폐쇄 정도 가 심한 환자들이 본 연구에 더 많은 분포를 차지하고 있어 연구 대상인 환자들의 특성에 차이가 있을 것으로 생각된

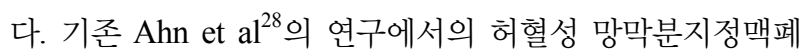
쇄의 포함 비율의 경우에도 본 연구에서 연구 대상의 더 많 은 분포를 차지하고 있는 것으로 보인다. 그리고 기존 연구 에서는 마지막 검사보다 빛간섭단층촬영에서 중심황반두 께가 $100 \mu \mathrm{m}$ 이상 증가하거나 최대교정시력이 $0.1 \log \mathrm{MAR}$ 이상 감소하는 경우 또는 중심황반두께가 $300 \mu \mathrm{m}$ 이상이 거나 최대교정시력이 20/40 미만인 경우 재주사를 시행하 였으나, 본 연구는 후향적 연구로서 기존 연구들과 달리 재 주사 시행 기준이 덜 엄격하였던 것도 결과를 해석할 때 고 려해야 할 것으로 생각된다. 3 monthly군과 PRN군에 대한 연구 결과는 다양한 이견이 있으며 앞으로 더 많은 연구가 필요할 것으로 생각된다.

본 연구는 또한 황반부종이 동반된 망막분지정맥폐쇄에 서 기능적 호전과 해부학적 호전과 관련되는 예측인자를 분석하였다. 다변량 회귀분석 결과 발병 시기부터 치료 시 작까지의 기간, 3 회 로딩, 치료 전 최대교정시력, 치료 전 망막내층손상, 치료 전 맥락막두께가 최대교정시력 호전 정도와 관련있는 유의한 예측인자였고, 연령, 3 회 로딩, 치 료 전 최대교정시력, 치료 전 망막내층손상이 최종 시력과 관련된 유의한 예측인자였다. 발병 시점부터 치료 시작까 지의 기간, 치료 전 중심황반두께, 치료 전 맥락막두께는 중심황반두께 감소 정도와 관련되는 유의한 예측인자였다. Lloyd Clark et $\mathrm{al}^{29}$ 은 망막정맥폐쇄환자에서 초기 최대교정 시력이 좋은 경우, 전체 황반 볼륨이 큰 경우, 망막하액이 존재하는 경우 최종적으로 더 빠른 시력호전을 보인다고 보고하였으며 Shin et $\mathrm{al}^{30}$ 은 초기 최대교정시력이 좋은 경 우, 빛수용체타원체구역이 보존된 경우 좋은 최종 시력과 유의한 관계가 있다고 하였다. Středová et $\mathrm{al}^{31}$ 은 망막분지 정맥폐쇄 환자에서 어린 나이, 짧은 유병 기간, 초기시력이 안 좋을수록 시력호전 정도가 더 큰 치료 효과를 보였다고 보고하였다.

망막내층손상은 빛간섭단층촬영에서 신경절세포층, 내망 상층, 내핵층과 외망막상층의 경계가 불명확해진 부위를 의미하며 당뇨망막병증, 망막정맥폐쇄 등 혈관질환에서 시 력예후가 불량할 수 있음을 예측할 수 있는 생물학적 지표 로 황반부의 모세혈관 비관류 부위와 무혈관 부위의 확립 이 망막내층손상과 연관된다고 알려져 있다. ${ }^{32}$ Babiuch et $\mathrm{al}^{18}$ 에서는 망막분지정맥폐쇄 환자 중 치료 전 망막내층손 상이 있는 군에서 치료 전 최대교정시력이 낮았으며, 유리 체내 항혈관내피인자주입술 후 시력호전 정도가 망막내층
손상이 있는 군에서 시력호전이 낮음을 보고하였고, 본 연 구에서도 망막내층손상이 최대교정시력 호전 정도 뿐 아니 라 최종 시력과 관련된 유의한 예측인자로 비등한 결과를 보였다. 또한 Suzuki et $\mathrm{al}^{33}$ 은 망막내층손상과 망막분지정 맥폐쇄 환자의 황반부종 재발과 유의한 상관관계가 있음을 발표한 바 있다.

맥락막혈류는 신체에서 단위 면적당 혈류량이 가장 많은 곳으로 망막외층의 정상적인 신진대사를 충족시키기 위해 필요하다. 구조적 및 기능적으로 정상 맥락막혈관 구조는 망막의 기능을 위해 필수적이며, 맥락막 자체가 시력을 위 해 매우 중요하다. 상대적으로 두꺼운 기저 맥락막두께를 가진 눈은 황반부종으로부터 회복할 가능성이 증가한다고 볼 수 있다. ${ }^{34-36}$ Song et $\mathrm{al}^{37}$ 은 망막분지정맥폐쇄 환자에서 병변이 발생한 부위가 병변이 발생하지 않은 부위에 비해 맥락막의 두께가 더 높게 측정된다고 보고하였으며, 망막 저산소증으로 혈관내피세포성장인자의 발현 증가로 안구 혈관의 투과성이 높아지면서 저산소 상태의 망막에 인접한 맥락막의 확장과 두꺼워짐을 유발할 수 있다고 발표한 바 있다. Coban-Karatas et $\mathrm{al}^{19}$ 은 망막분지정맥폐쇄가 있는 안 에서 정상안에 비하여 맥락막두께가 두꺼웠으며 항혈관내 피세포성장인자 주입술 치료 후 맥락막두께가 정상안과 비 슷한 두께로 돌아오는 결과를 보고하였으며 이에 대하여 혈관내피세포성장인자의 발현 증가가 맥락막두께의 증가 를 유발한다고 설명하고 있다. Rayess et $\mathrm{al}^{38}$ 은 망막분지정 맥폐쇄 환자에서 최대교정시력이 2줄 이상 호전된 환자들 을 기능적 반응군으로, 그렇지 않았던 환자들을 기능적 비 반응군으로 분류하여 분석한 결과, 기능적 반응군의 망막 분지정맥폐쇄안에서 맥락막두께는 기능적 반응군의 정상 안 뿐 아니라 기능적 비반응군의 망막분지정맥폐쇄안의 맥 락막두께 비교에서도 유의하게 높다고 보고하였으며 치료 전 맥락막두께가 클수록 항내피세포성장인자 주입술 후 시 력호전 정도가 반응이 크다고 보고하였다. 이러한 황반부 종이 동반된 망막분지정맥폐쇄에서 맥락막두께가 두꺼울 수록 시력호전 정도가 좋은 것은 망막외층으로 관류가 보 존될 수 있어 시력호전에 대한 잠재적 가능성이 높아질 수 있다고 생각된다. 또한 맥락막두께가 두꺼울수록 항혈관내 피성장인자의 수치가 높기 때문에 항혈관내피성장인자에 대한 반응 또한 높아져서 더 큰 기능적 호전을 보일 수 있 다고 생각된다. An et $\mathrm{al}^{39}$ 은 황반부종을 동반한 망막분지정 맥폐쇄 환자의 방수에서 혈관내피성장인자 $\mathrm{A}$ 와 염증성 사 이토카인 수치를 측정하여 시력호전 정도 및 중심황반두께 감소 정도와 관련된 요소를 분석하고, 맥락막두께와 염증 성 사이토카인의 관계를 조사하였다. 다중회귀분석 결과 방수의 IL-8 농도가 6개월 동안의 시력호전 정도 및 중심황 
반두께 감소 정도와 유의한 관계가 있음을 보고하였다. 또 한 방수의 혈관내피성장인자 A 농도가 기저 맥락막두께 비 율(망막분지정맥폐쇄안의 맥락막두께/정상안의 맥락막두 께)과 유의한 상관관계가 있음을 발표하였다. 맥락막두께 가 두꺼울수록 방수의 수용성 혈관내피성장인자 수용체 2 와 IL-8의 농도가 높게 측정되고 얇은 맥락막두께를 가진 군 과 비교하여 더 나은 시력호전 정도와 더 큰 중심황반두께 의 감소를 보임을 보고하였다. 이저럼 저자들도 망막분지 정맥폐쇄에서 두꺼운 기저 맥락막두께는 더 좋은 치료 결 과를 예측할 수 있는 인자로 생각되며 이는 환자들의 안 내 의 염증성 사이토카인의 높은 농도와 관련성이 있다고 사 료된다.

결론적으로 망막분지정맥폐쇄의 황반부종에서 3 monthly 군은 non-3 monthly군에 비하여 단기적인 기능적 및 해부 학적 호전과 장기적인 기능적 호전에 치료 우위적 효과를 기대할 수 있었다. 초기 매달 3회 집중적인 치료는 망막의 구조적 이상이 지속되는 기간이 단축되어 비가역적 손상을 줄일 수 있고, 혈액망막장벽의 파괴와 염증반응을 조기에 조절하여 추가적인 손상을 감소시켜 비가역적 저하를 줄이고 최종 시력호전을 높일 수 있다고 생각된다. 하지만 본 연구 의 제한점으로 non-3 monthly군 41안에 비하여 3 monthly 군이 21 안으로 상대적으로 적었다는 점, 망막분지정맥폐쇄 의 정도에 따른 분석을 할 수 없었다는 점, 의무기록을 후 향적으로 분석한 연구로 여러 종류의 항혈관내피성장인자 약제 선택 및 유리체내 베바시주맙주입술 스케줄 선택과 재치료에 있어서 엄격한 기준을 적용하지 못하였다는 점, 12 개월 이상 관찰 가능하였던 환자들을 대상으로 하였기에 이에 대한 선택 바이어스(selection bias)가 작용하였을 가 능성이 있어 이를 염두에 두고 결과를 해석해야 할 것이다. 추후 더 많은 환자군을 포함하고 12 개월 이상의 장기적인 관찰과 연구가 시행된다면 황반부종이 동반된 망막분지정 맥폐쇄 환자의 치료에 도움이 될 수 있을 것으로 생각된다.

\section{REFERENCES}

1) Cakir M, Dogan M, Bayraktar Z, et al. Efficacy of intravitreal triamcinolone for the treatment of macular edema secondary to branch retinal vein occlusion in eyes with or without grid laser photocoagulation. Retina 2008;28:465-72.

2) Rogers SL, McIntosh RL, Lim L, et al. Natural history of branch retinal vein occlusion: an evidence-based systematic review. Ophthalmology 2010;117:1094-101.e5.

3) Noma H, Mimura T, Yasuda K, Shimura M. Cytokine kinetics after monthly intravitreal bevacizumab for retinal vein occlusion associated with macular oedema. Ophthalmic Res 2016;56:207-14.

4) Shchuko AG, Zlobin IV, Yur'eva TN, et al. Intraocular cytokines imbalance in retinal vein occlusion and its impact on the efficacy of anti-angiogenic therapy. Vestn Oftalmol 2015;131:50-8.

5) Noma H, Mimura T. Aqueous soluble vascular endothelial growth factor receptor-2 in macular edema with branch retinal vein occlusion. Curr Eye Res 2013;38:1288-90.

6) The Branch Vein Occlusion Study Group. Argon laser photocoagulation for macular edema in branch vein occlusion. Am J Ophthalmol 1984;98:271-82.

7) Scott IU, Ip MS, VanVeldhuisen PC, et al. A randomized trial comparing the efficacy and safety of intravitreal triamcinolone with standard care to treat vision loss associated with macular edema secondary to branch retinal vein occlusion: the Standard Care vs Corticosteroid for Retinal Vein Occlusion (SCORE) study report 6. Arch Ophthalmol 2009;127:1115-28.

8) Higashiyama T, Sawada O, Kakinoki M, et al. Prospective comparisons of intravitreal injections of triamcinolone acetonide and bevacizumab for macular oedema due to branch retinal vein occlusion. Acta Ophthalmol 2013;91:318-24.

9) Jonas JB, Akkoyun I, Kamppeter B, et al. Branch retinal vein occlusion treated by intravitreal triamcinolone acetonide. Eye (Lond) 2005; 19:65-71.

10) Yepremyan M, Wertz FD, Tivnan T, et al. Early treatment of cystoid macular edema secondary to branch retinal vein occlusion with intravitreal triamcinolone acetonide. Ophthalmic Surg Lasers Imaging 2005;36:30-6.

11) Campochiaro PA, Heier JS, Feiner L et al. Ranibizumab for macular edema following branch retinal vein occlusion: six-month primary end point results of a phase III study. Ophthalmology 2010; 117:1102-12.e1.

12) Campochiaro PA, Clark WL, Boyer DS, et al. Intravitreal aflibercept for macular edema following branch retinal vein occlusion: the 24-week results of the VIBRANT study. Ophthalmology 2015;122:538-44.

13) Yunoki T, Miyakoshi A, Nakamura $T$, et al. Treatment of macular edema due to branch retinal vein occlusion with single or multiple intravitreal injections of bevacizumab. Jpn J Ophthalmol 2012;56: 159-64.

14) Moradian S, Faghihi H, Sadeghi B, et al. Intravitreal bevacizumab vs. sham treatment in acute branch retinal vein occlusion with macular edema: results at 3 months (report 1). Graefes Arch Clin Exp Ophthalmol 2011;249:193-200.

15) Rabena MD, Pieramici DJ, Castellarin AA, et al. Intravitreal bevacizumab (Avastin) in the treatment of macular edema secondary to branch retinal vein occlusion. Retina 2007;27:419-25.

16) Figueroa MS, Contreras I, Noval S, Arruabarrena C. Results of bevacizumab as the primary treatment for retinal vein occlusions. Br J Ophthalmol 2010;94:1052-6.

17) Osaka R, Nakano Y, Takasago Y, et al. Retinal oximetry in branch retinal vein occlusion. Acta Ophthalmol 2019;97:e896-901.

18) Babiuch AS, Han M, Conti FF, et al. Association of disorganization of retinal inner layers with visual acuity response to anti-vascular endothelial growth factor therapy for macular edema secondary to retinal vein occlusion. JAMA Ophthalmol 2019;137:38-46.

19) Coban-Karatas M, Altan-Yaycioglu R, Ulas B, et al. Choroidal thickness measurements with optical coherence tomography in branch retinal vein occlusion. Int J Ophthalmol 2016;9:725-9.

20) Yang HN, Kim YJ, Kim JC, Shyn KH. Clinical evaluation for branch retinal vein occlusion. J Korean Ophthalmol Soc 1992;33: 599-604. 
21) Campochiaro PA, Bhisitkul RB, Shapiro H, Rubio RG. Vascular endothelial growth factor promotes progressive retinal nonperfusion in patients with retinal vein occlusion. Ophthalmology 2013;120: 795-802.

22) Ota M, Tsujikawa A, Miyamoto K, et al. Visual acuity following intravitreal bevacizumab for macular edema associated with retinal vein occlusion. Jpn J Ophthalmol 2010;54:555-64.

23) Noma H, Mimura T, Yasuda K, et al. Cytokines and recurrence of macular edema after intravitreal ranibizumab in patients with branch retinal vein occlusion. Ophthalmologica 2016;236:228-34.

24) Noma H, Mimura T, Yasuda K, et al. Intravitreal ranibizumab and aqueous humor factors/cytokines in major and macular branch retinal vein occlusion. Ophthalmologica 2016;235:203-7.

25) Ozdek S, Deren YT, Gurelik G, Hasanreisoglu B. Posterior subtenon triamcinolone, intravitreal triamcinolone and grid laser photocoagulation for the treatment of macular edema in branch retinal vein occlusion. Ophthalmic Res 2008;40:26-31.

26) Miwa Y, Muraoka Y, Osaka R, et al. Ranibizumab for macular edema after branch retinal vein occlusion: one initial injection versus three monthly injections. Retina 2017;37:702-9.

27) Ito $Y$, Saishin $Y$, Sawada O, et al. Comparison of single injection and three monthly injections of intravitreal bevacizumab for macular edema associated with branch retinal vein occlusion. Clin Ophthalmol 2015;9:175-80.

28) Ahn SJ, Ahn J, Woo SJ, Park KH. Initial dose of three monthly intravitreal injections versus PRN intravitreal injections of bevacizumab for macular edema secondary to branch retinal vein occlusion. Biomed Res Int 2013;2013:209735.

29) Lloyd Clark W, Liu M, Kitchens J, et al. Baseline characteristics associated with early visual acuity gains after ranibizumab treatment for retinal vein occlusion. BMC Ophthalmol 2019;19:11.

30) Shin HJ, Chung H, Kim HC. Association between integrity of foveal photoreceptor layer and visual outcome in retinal vein occlusion. Acta Ophthalmol 2011;89:e35-40.

31) Středová M, Stepanov A, Studnička J, et al. Ranibizumab in macular oedema secondary to branch retinal vein occlusion-24 months of treatment. Cesk Slov Oftalmol 2019;75:190-8.

32) Nicholson L, Ramu J, Triantafyllopoulou I, et al. Diagnostic accuracy of disorganization of the retinal inner layers in detecting macular capillary non-perfusion in diabetic retinopathy. Clin Exp Ophthalmol 2015;43:735-41.

33) Suzuki M, Nagai N, Minami S, et al. Predicting recurrences of macular edema due to branch retinal vein occlusion during anti-vascular endothelial growth factor therapy. Graefes Arch Clin Exp Ophthalmol 2020;258:49-56.

34) Arifoglu HB, Duru N, Altunel O, et al. Short-term effects of intravitreal dexamethasone implant (OZURDEX $\left.{ }^{\circledR}\right)$ on choroidal thickness in patients with naive branch retinal vein occlusion. Arq Bras Oftalmol 2016;79:243-6.

35) Rayess N, Rahimy E, Ying GS, et al. Baseline choroidal thickness as a predictor for treatment outcomes in central retinal vein occlusion. Am J Ophthalmol 2016;171:47-52.

36) Kim KH, Lee DH, Lee JJ, et al. Regional choroidal thickness changes in branch retinal vein occlusion with macular edema. Ophthalmologica 2015;234:109-18.

37) Song MR, Kim JS, Choi J, Park JH. Changes in choroidal thickness in branch retinal vein occlusion. J Korean Ophthalmol Soc 2016;57:1222-7.

38) Rayess N, Rahimy E, Ying GS, et al. Baseline choroidal thickness as a short-term predictor of visual acuity improvement following antivascular endothelial growth factor therapy in branch retinal vein occlusion. Br J Ophthalmol 2019;103:55-9.

39) An Y, Park SP, Kim YK. Aqueous humor inflammatory cytokine levels and choroidal thickness in patients with macular edema associated with branch retinal vein occlusion. Int Ophthalmol 2021;41:2433-44. 


\section{= 국문초록 $=$}

\section{망막분지정맥폐쇄에 동반된 황반부종에서 베바시주맙치료 결과}

목적: 망막분지정맥폐쇄에 동반된 황반부종에서 유리체내 베바시주맙주입술 방법에 따른 치료 결과를 알아보고자 한다.

대상과 방법: 망막분지정맥폐쇄에서 첫 치료로 유리체내 베바시주맙을 주입한 62명 62안에 관하여 후향적으로 분석하였다. 초기 한 달 간격으로 3회 로딩 치료에 성공한 21안과 그렇지 않은 그룹 41안을 대상으로 주사 전과 주사 후 시기별 최대교정시력 및 빛간섭단 층촬영의 소견 변화와 예후 관련인자를 분석하였다.

결과: 최대교정시력은 초기 3 회 주입군에서 3 회 로딩으로 치료하지 않은 군보다 3 개월, 6 개월, 12 개월째 더 큰 호전을 보였다 $(p=0.025, p=0.019, p=0.008)$. 중심황반두께는 6 개월째 초기 3 회 주입군에서 3 회 로딩으로 치료하지 않은 군보다 더 큰 호전을 보였 다 $(p=0.034)$. 다변량 회귀분석 결과 증상 발현 기간, 3 회 로딩, 최대교정시력, 망막내층손상, 맥락막두께가 시력호전 정도와 관련된 예측인자였으며 $(p=0.044, p=0.047, p=0.004, p=0.045, p=0.034)$, 연령, 3 회 로딩, 최대교정시력, 망막내층손상이 최종 시력과 관련 된 예측인자로 나타났다 $(p=0.045, p=0.046, p=0.002, p=0.034)$. 증상 발현 기간, 중심황반두께, 맥락막두께가 중심황반두께 호전에 관련된 예측인자로 나타났다 $(p=0.042, p=0.009, p=0.015)$.

결론: 망막분지정맥폐쇄의 황반부종에서 유리체내 베바시주맙 초기 3회 주입은 3회 로딩으로 치료하지 않은 방법에 비하여 단기적인 기능적 및 해부학적 호전과 장기적인 기능적 호전에 치료 우위적 효과를 보였다.

〈대한안과학회지 2021;62(9):1207-1217〉

최유진 / Yu-Jin Choi 경상국립대학교 의과대학 안과학교실 Department of Ophthalmology, Gyeongsang National University School of Medicine

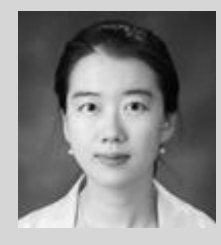

